\title{
Ethnobiology of algarroba beer, the ancestral fermented beverage of the Wichí people of the Gran Chaco I: a detailed recipe and a thorough analysis of the process
}

\author{
Anahí Naymé Herrera Cano ${ }^{1,2}$ and María Eugenia Suárez ${ }^{1,3^{*}}$ (iD
}

\begin{abstract}
Algarroba (Prosopis alba) beer, known as aloja de algarroba (abbreviated aloja) in local Spanish, is the ancestral alcoholic beverage par excellence of the Wichís and other indigenous peoples of South American Gran Chaco, but nowadays is in disuse. Mentions on the recipe exist, but they are relatively few, concise and/or partial, and most of them were not registered within ethnobiological studies. The aims of this study were to (a) describe in detail the preparation process of algarroba beer and (b) analyse the process from a holistic approach, integrating Wichí concepts and biological explanations. Any morphological type of Prosopis alba fruits is useful, except those with poor mesocarp. Aloja must be prepared from relative fresh fruits, ground into pieces and not from flour alone. Through the senses, mainly taste and smell, the procedure is followed until optimal fermentation time is reached, which occurs at 24-48 h. When aloja is ready, it tastes tapay (bitter-sour) or nusuy (sour-salty). From the Wichí perspective, fermentation is both a maturation and a cooking process, and it is the "strength" (qahay, qahnayaj) of the pods, an intrinsic property, which allows fermentation to occur, with alcohol production. All interviewees' remarks about the recipe are also explained by microbiological concepts. Altogether, results expand the knowledge on Wichí ethnobiology and are also useful to other disciplines interested in traditional food systems. Besides, they constitute a contribution to the rescue of the know-how on this traditional beverage for future generations and ultimately to food sovereignty.
\end{abstract}

Keywords: Ethnobotany, Ethnozymology, Indigenous people, Argentina, Chicha, Aloja, Gastronomic ethnobiology, Food sovereignty, Prosopis alba

\section{Introduction}

The study of fermented beverages is an important topic for ethnobiology and other disciplines interested in food systems of indigenous peoples, as they are products of a bio-cultural heritage which has evolved through centuries of interactions between local societies and their environment, and thus they are a significant tool for

\footnotetext{
* Correspondence: eugesuarez78@gmail.com

'Departamento de Biodiversidad y Biología Experimental, Grupo de Etnobiología, Facultad de Ciencias Exactas y Naturales, Universidad de Buenos Aires, Buenos Aires, Argentina

${ }^{3}$ Instituto de Micología y Botánica (INMIBO), CONICET-UBA, Buenos Aires, Argentina

Full list of author information is available at the end of the article
}

sustaining local traditional foods and implementing food sovereignty $[1,2]$. Fermented beverages have high nutritional values and are a source of probiotics [3]. However, their preparation requires detailed and rigorous knowledge, as an adequate synergy must take place among several microorganisms for the appropriate fermentation process to occur (see $[4,5])$. Indigenous traditional knowledge occupies here a relevant, unique place. In this sense, and because these beverages have suffered great discredit all over the world during colonisation of indigenous societies, studies aiming to record and to show their cultural relevance are important and necessary, especially considering that cases of recuperation of

(C) The Author(s). 2020 Open Access This article is distributed under the terms of the Creative Commons Attribution 4.0 International License (http://creativecommons.org/licenses/by/4.0/), which permits unrestricted use, distribution, and 
traditional fermented beverages in local contexts already exist (e.g. [6]).

From time immemorial, the alcoholic beverage par excellence of numerous indigenous peoples of the South American Gran Chaco region (Fig. 1a) is the algarroba beer, called aloja de algarroba (usually abbreviated aloja) in local Spanish (see [7-9]). It is made from water and Prosopis alba Griseb. (Fabaceae) pods, called algarrobas. This species, locally known as algarrobo or algarrobo blanco, is native to several countries of South America and is a typical tree of the Gran Chaco region [10]. For the different peoples native to this region, the Wichís being one of them, this species is of great cultural significance, both at practical and symbolic levels [11].

The Wichís are a society of approximately 55,000 people with a non-centralised political organisation forming a broad network of rural and peri-urban communities that extends through Salta, Formosa and Chaco provinces in the north of Argentina and a small fringe of South East Bolivia [12-15] (Fig. 1b, c). Here, the Wichís are neighbours to other native peoples of the Gran Chaco (Choroti, Pilagá, Toba, among others), and since the nineteenth century, they have coexisted with the Criollos (locally born settlers of Hispanic heritage, most of them mestizos) [12, 13]. Wichís are of an oral tradition; their native language is the Wichi-lhamtes or Wichí, an Indo-American language of the Mataco-Mataguayo linguistic family, which has several regional variations. Wichi-lhamtes has a high vitality: most people speak it as their first language, and many of them, especially old women and small children, are monolingual [16, 17]. In essence, Wichís are nomadic hunters-gatherers-fishers, although for several decades, they have been forced to live sedentarily and to gradually add to their traditional activities new forms of subsistence according to the capitalist production system. The tasks undertaken by Wichí men and women are traditionally well differentiated and clearly distributed: men are mainly hunters, fishermen, manufacturers of wooden handicrafts and wage earners working for the criollos; women basically spend their time gathering, doing housework and manufacturing textile handicrafts $[12,13,17]$.

For the Wichí people, algarroba beer (called jwa'ayhat'es in Wichí) was a vital element of their social life. This beverage had a central role in some rites, like feminine initiation and rituals associated to war [13, 18], but above all it was a central and essential element in festivities named yachep, known in Spanish as fiestas de la algarroba (algarroba festivities) or fiestas de la aloja (aloja festivities). These ceremonies took place every year during the hot seasons, in order to celebrate the maturation of the fruits of the forest and the arrival of the time of abundance [19]. These rites were the only occasions in which alcohol was consumed in Wichí society in the past. Since the 1910s, with the arrival of the Anglican Church to the region [20], these rituals continuously decreased until their disappearance in the middle of the twentieth century. Currently, aloja consumption persists in reduced contexts, for small groups or for individual use; however, in general terms, it is in disuse, especially among young generations. Industrial alcoholic drinks (barley beer, low-quality wine) have replaced traditional fermented beverages, and alcoholism is dramatically increasing $[17,21]$.

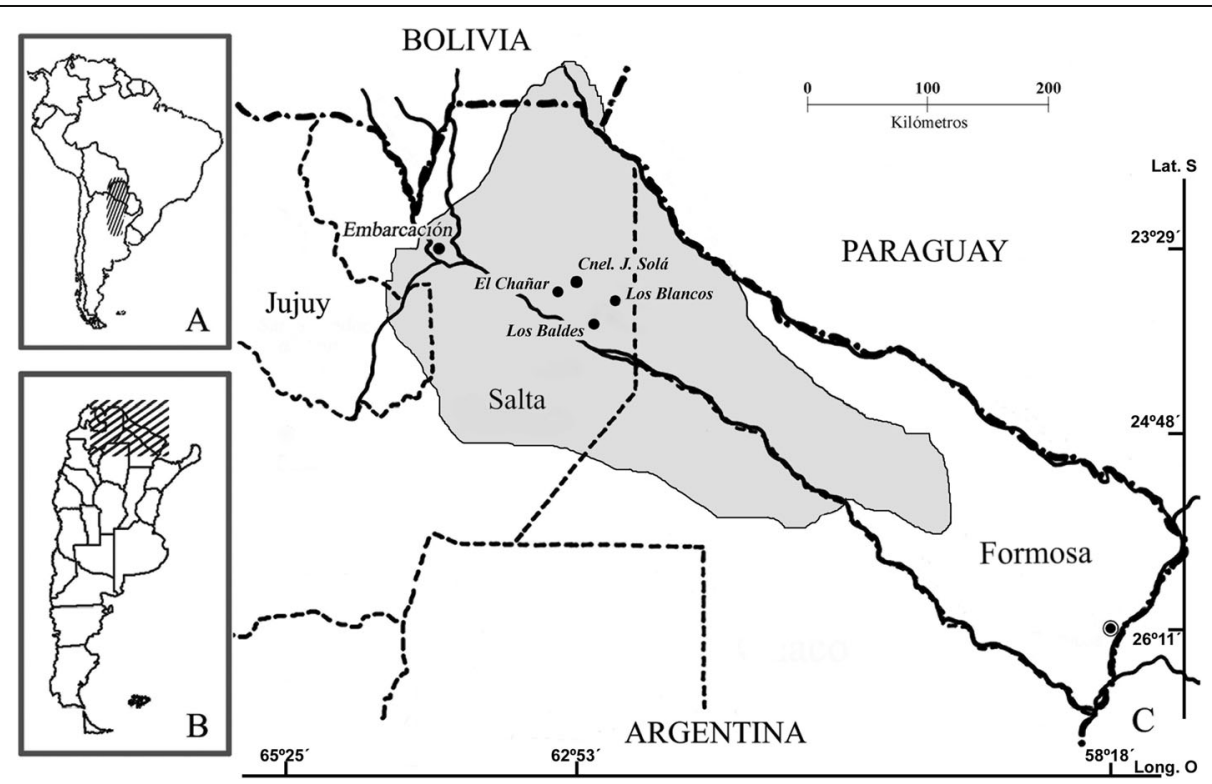

Fig. 1 a The Gran Chaco region in South America. $\mathbf{b}$ The study area in Argentina. c Map of the study area with the approximated distribution of the Wichí people (outlined in grey) 
Aloja's contexts of use and its consumption significance have been widely studied, mainly by anthropologists, including the roles of men, women and shamans, as well as related rites and myths (e.g. [13, 18, 19, 21]). However, data on the details of the preparation process are scarce, mostly succinct and partial, and/or they are dispersed in several bibliographical references, and some seem somewhat contradictory. Besides, except the work of Arenas [12], who includes aloja within a large study on Wichí and Qom (another Chaco indigenous people) food systems, there aren't studies that dig into the ethnobiology of this beverage, especially its preparation. Regarding microbiological and physical-chemical properties of this beverage, except the study of Sciammaro [22], who analyses aloja prepared according to recipes provided by Criollos (i.e. mestizos), studies on this matter are also scarce and partial.

The aims of this study are to (a) describe in detail the preparation process of algarroba beer and (b) analyse the process from a holistic approach, integrating Wichí concepts and biological explanations. Altogether, the results may expand the knowledge on Wichí ethnobiology and provide useful information for other disciplines interested in traditional food systems. Besides, they may be a contribution to the rescue of the know-how on this traditional beverage for future generations and ultimately to food sovereignty.

\section{Methods}

This ethnobiological research is based on original information and is developed from a qualitative approach [23, 24]. Primary data was gathered during 11 field expeditions made between 2005 and 2017 to several Wichí settlements located at the east of Salta Province (Argentina), with each visit lasting a month on average. During those field trips, many aspects of Wichí ethnobiology were studied, including the aloja de algarroba. However, during two of them (carried out in February 2014 and November-December 2017), emphasis was placed on the study of this topic for the purposes of this particular research. A total of 26 Wichí adults, 15 men and 11 women, between 35 and 85 years old, provided thorough information on the topic. They live in seven different settlements: four of them (Cacique Catán, El Chañar II, La Cortada, La Represa) are located in the outskirts of the town Coronel Juan Solá (known as Morillo), another one is located in the town Los Blancos, and the remaining two (Misión Los Baldes, Misión El Chañar) are Wichí rural villages located 20-35 $\mathrm{km}$ to the south of those towns (Fig. 1c). Prior informed consent was obtained orally from the community authorities and from each interviewee. Data and materials were obtained through open-ended and semi-structured interviews, the "walk-through-the-forest" technique, observation and participant observation [23, 25]. Data was always recorded in fieldwork books, and sometimes photographs and video records were taken with the permission of the interviewees. Additionally, when asking about vernacular nomenclature and morphology of Prosopis alba trees and fruits, plant material (fruits and leafy branches) were used as auxiliary material. In 9 opportunities, authors participated in the preparation of aloja, from the recollection of algarrobo fruits until the beverage was ready, documenting pertinent details all through the process. During the walks-through-the-forest, vouchers of Prosopis alba were gathered. In the laboratory, vouchers were identified by the first author and were deposited in an official herbarium (BA). Botanical identifications were made using specific studies and taxonomic keys $[10,26]$ and have been checked with World Flora Online [27]. All the information was transcribed and organised ad hoc into digital databases, and a holistic interpretative analysis was carried out. Wichí expressions are written according to the vocabulary used by Suárez [17]; those taken from the literature were adapted to it.

\section{Results and discussion}

The main ingredient: jwa'ay (Prosopis alba fruits)

The fruits of algarrobo blanco (jwa'ayukw) are called jwa'ay (sing. jwa'a) in Wichi-lhamtes and algarrobas in local Spanish. When the pods are mature $(y u)$, which occurs at the end of springtime or at the beginning of the summer, women (who are traditionally in charge of recollection activities) go into the forest to collect large amounts of fruits (Fig. 2). But are all kinds of pods optimal for preparing aloja? It is known that leaves and fruits of Prosopis alba exhibit high morphological variability [10]. Table 1 summarises the information regarding 24 specimens of Prosopis alba that were studied, including voucher numbers, photos of the fruits, suitability for preparing aloja, vernacular nomenclature of trees and fruits and its meanings and translations into English. As observed, all kinds of fruits are suitable for preparing aloja, except those called jwa'ay-t'ojes (algarrobas peels), because they have "scarce flesh" and are "dry", attributes that disqualified them as raw materials for the beverage. On the contrary, the preferred kinds of fruits are those with the opposite characteristics: large and/or fat, with a large amount of mesocarp. Besides, humid, decaying, broken, dirty or infested pods are not collected, and neither are fruits considered to be ka'ali (patalca in local Spanish), described as insipid, not sweet enough, without the optimal flavour. Algarrobas may be $k a$ 'ali because they are immature (jwa'ay-watsan, green/immature algarrobas) or because they grow in specific trees that always produce mature pods that are ka'ali.

\section{The recipe in detail}

According to the interviewees, the recipe for algarroba beer, called jwa'ay-hat'es in Wichi-lhamtes (hat'es means alcoholic beverage) is as follows. Fresh fruits (collected 

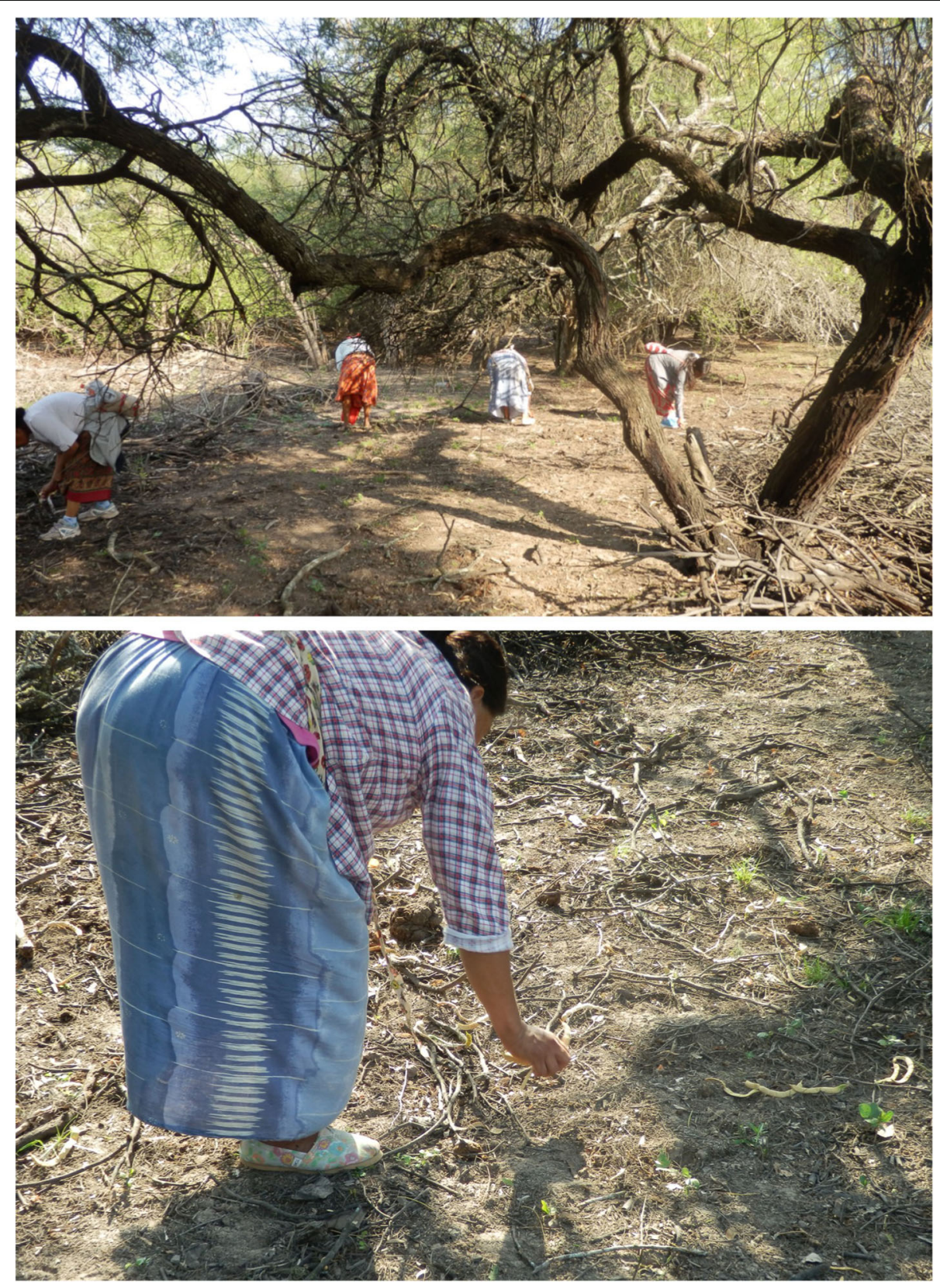

Fig. 2 In the forest, gathering Prosopis alba fruits. Mature P. alba pods fall into the ground and are manually gathered. Branches are also usually shuffled with a handmade wooden hookstick (k'ekw), so more mature fruits fall. To carry fruits home, large semi-spherical string bags called sichet made from foliar fibres of chagua (äletsaj, Bromelia urbaniana (Mez) L.B. Sm., or chitsaj, Bromelia hieronymi Mez.) were used by women in the past. They sat on their backs and were held from the forehead. Nowadays, they are in disuse and have been replaced by modern bags made of plastic or other materials. Traditional yicas (hilu), rectangular cross body bags made of chagua, are still used by women, men and children to carry their personal belongings in their daily lives

recently, not long-stored) are ground into pieces of 1-2 $\mathrm{cm}$ (Fig. 3a, b). This fragmented material is called jwa'ay-lhipey (algarrobas parts/pieces) or lhotay-jwa'ay (algarrobas pieces/fragments). If pods are somewhat dry, the hand of the mortar or the fruits itself can be moistened to avoid flour production while grinding. The ground material is then put into the fermentation container, and temperate water is added. The optimal proportion is approximately two parts of water per solid part; an excess of water may turn the beverage insipid (aqoj.it'e, not tasty). Then, ingredients must be stirred and the container covered. The preparation is left at rest for 24-48 h (Fig. 3c), which is the average optimal time. According to climatic conditions, the duration of the 
Table 1 Studied Prosopis alba specimens, including voucher code, Wichí name of the tree, Wichí names or descriptions of the fruits and their translation to English, photos of the specimen fruits and their suitability for preparing aloja

\begin{tabular}{ll}
\hline $\begin{array}{l}\text { Voucher code } \\
\text { Wichí name of tree }\end{array}$ & Wichí names or descriptions of fruits [translations to English] Photo \\
\hline AHC2 & Chuhu; Chuh(u)laj [twisted?] \\
Jwa'ayukw & Pitaj (pl. pites) [long]
\end{tabular}

$\mathrm{AHC} 3$

Jwa'ayukw

$\mathrm{AHC} 4$

Jwa'ayukw

AHC5

Jwa'ayukw

AHC6

Jwa'ayukw

AHC7

Jwa'ayukw

$\mathrm{AHC8}$

Jwa'ayukw

AHC9

Jwa'ayukw
Chuhu; Chuh(u)laj [twisted?]

Pitaj (pl. pites) [long]

Alhe-les [iguana offsprings]

Alhe-les layumles [short/little iguana offsprings] Lupen [thin]

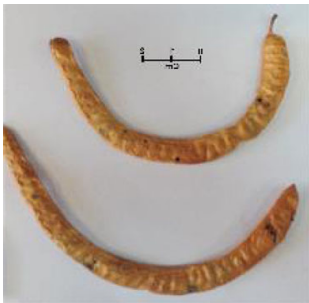

Alhe-les [iguana offsprings]

Lhomsaj (pl. lalémses) [small; small son]

Pitaj (pl. pites) [long]

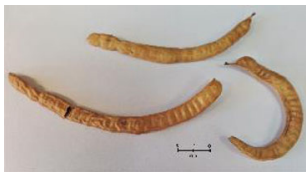

Pitaj (pl. pites) [long]

Yätaj [fat]

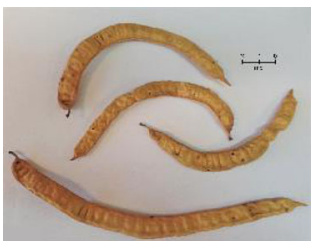

Alhe-les [iguana offsprings]

Pitaj (pl. pites) [long]

Yätaj [fat]

Wesche [large/big]

Alhe-les [iguana offsprings]

Pitaj (pl. pites) [long]
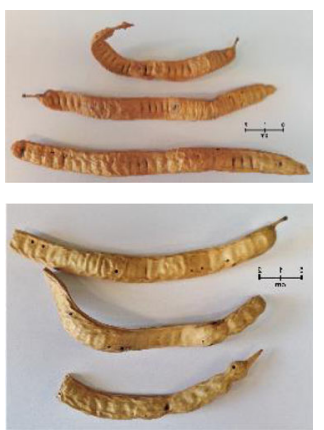

Yätaj [fat]

Yätaj [fat]

Pitaj (pl. pites) [long]

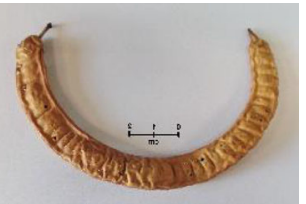

Yes

Yes

Yes

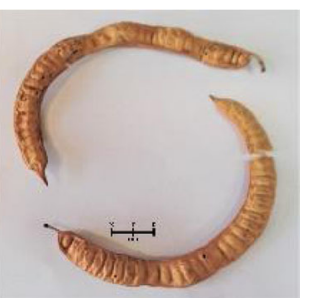


Table 1 Studied Prosopis alba specimens, including voucher code, Wichí name of the tree, Wichí names or descriptions of the fruits and their translation to English, photos of the specimen fruits and their suitability for preparing aloja (Continued)

\begin{tabular}{|c|c|c|c|}
\hline $\begin{array}{l}\text { Voucher code } \\
\text { Wichí name of tree }\end{array}$ & Wichí names or descriptions of fruits [translations to English] & Photo & $\begin{array}{l}\text { Suitable for } \\
\text { aloja }\end{array}$ \\
\hline $\begin{array}{l}\text { AHC10 } \\
\text { Jwa'ayukw }\end{array}$ & $\begin{array}{l}\text { Chuhu; Chuh(u)laj [twisted?] } \\
\text { Yesnu-käsley [quirquincho's (Tolypeutes matacus) guts] }\end{array}$ & & Yes \\
\hline $\begin{array}{l}\text { AHC11 } \\
\text { Jwa'ayukw }\end{array}$ & $\begin{array}{l}\text { Chuhu; Chuh(u)laj [twisted?] } \\
\text { Watsan [green; immature] }\end{array}$ & & No \\
\hline $\begin{array}{l}\text { AHC12 } \\
\text { Jwa'ayukw }\end{array}$ & Chuhu; Chuh(u)laj [twisted?] & & Yes \\
\hline $\begin{array}{l}\text { AHC13 } \\
\text { Jwa'ayukw }\end{array}$ & $\begin{array}{l}\text { Yätaj [fat] } \\
\text { Pitaj (pl. pites) [long] }\end{array}$ & . & Yes \\
\hline
\end{tabular}

$\mathrm{AHC15}$

Jwa'ayukw

AHC16

Jwa'ayukw

AHC19

Jwa'ayukw

$\mathrm{AHC20}$

Jwa'ayukw
Pitaj (pl. pites) [long]

Alhe-les [iguana offsprings]

Wesche [large/big]

Yätaj [fat]

Chuhu; Chuh(u)laj [twisted?]

Lhomsaj (pl. lalémses) [small; small son] Watsan [green; immature]

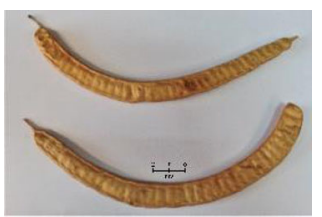

Yes
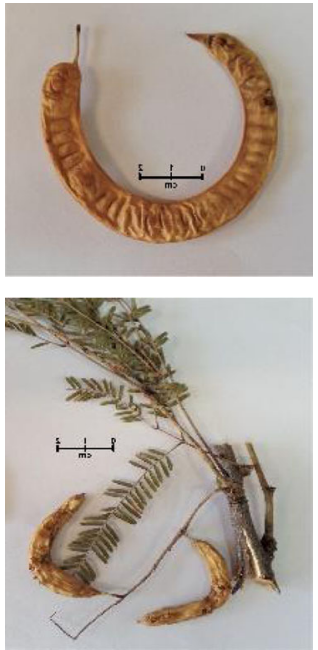

No

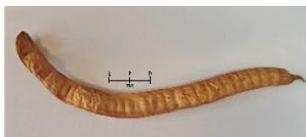


Table 1 Studied Prosopis alba specimens, including voucher code, Wichí name of the tree, Wichí names or descriptions of the fruits and their translation to English, photos of the specimen fruits and their suitability for preparing aloja (Continued)

\begin{tabular}{ll}
\hline $\begin{array}{l}\text { Voucher code } \\
\text { Wichí name of tree }\end{array}$ & Wichí names or descriptions of fruits [translations to English] Photo \\
\hline $\begin{array}{l}\text { AHC21 } \\
\text { (Prosopis aff. alba) } \\
\text { Jwa'ayukw }\end{array}$ & $\begin{array}{l}\text { Alhe-les [iguana offsprings] } \\
\text { Chuhu; Chuh(u)laj [twisted?] } \\
\text { Layúmles-jwa'ay [short/little algarrobas] }\end{array}$ \\
$\begin{array}{ll}\text { AHC24 } \\
\text { Jwa'ayukw }\end{array}$ & $\begin{array}{l}\text { Pitaj (pl. pites) [long] } \\
\text { Chuhu; Chuh(u)laj [twisted?] }\end{array}$ \\
&
\end{tabular}

HCyS 25

Jwa'ayukw

Jwa'a-tek (anomalous jwa'ayukw, anomalous algarrobas) ${ }^{b}$

HCyS26

(Prosopis aff. alba)

Jwa'ayukw

HCyS27

Jwa'ayukw

MES651

Jwa'ayukw

MES652

Jwa'ayukw
Jwa'atek-Ihay [fruits of jwa'atek]

Seynlhey [withered algarrobas]

Jwa'ay-tas/Jwa'a-tak [anomalous algarrobas/anomalous algarroba]

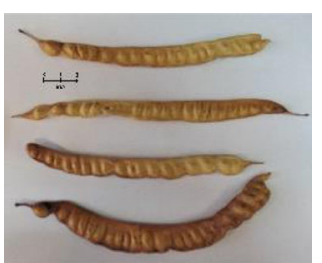

Lupen [thin]

Chuhu; Chuh(u)laj [twisted?]

Jwa'ay-t'ojes [algarroba peels]

Jwa'ay-t'ojes [algarroba peels]

Lupen [thin]

Chuhu; Chuh(u)laj [twisted?]

Seynlhey [withered algarrobas]

Pitaj (pl. pites) [long]

Tokjwaj-yute-Ihiley [Tokjwaj's earring (Tokjwaj is a character of Wichí mythology)]
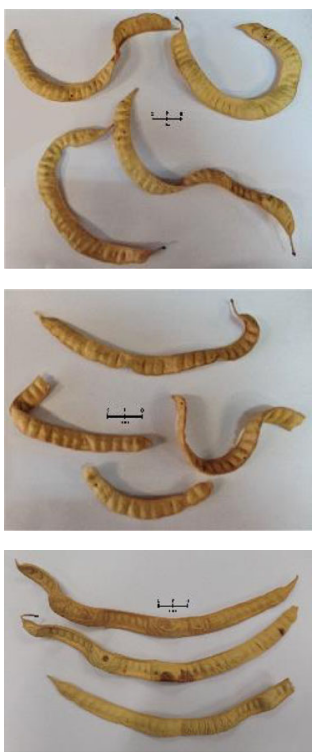

Yes

No

No

Yes

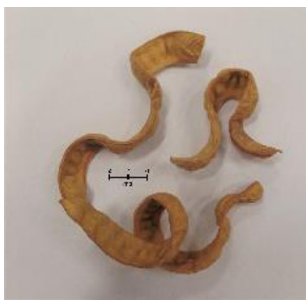


Table 1 Studied Prosopis alba specimens, including voucher code, Wichí name of the tree, Wichí names or descriptions of the fruits and their translation to English, photos of the specimen fruits and their suitability for preparing aloja (Continued)

\begin{tabular}{ll}
\hline $\begin{array}{l}\text { Voucher code } \\
\text { Wichí name of tree }\end{array}$ & Wichí names or descriptions of fruits [translations to English] Photo \\
\hline MES653 & Alhe-les [iguana offsprings] \\
Jwa'ayukw & Jwa'ay-t'ojes [algarroba peels] \\
MES654 & \\
Jwa'ayukw &
\end{tabular}

References: Voucher collector: AHC Anahí Herrera Cano, MES Maria Eugenia Suarez, HCyS Anahi Herrera Cano and Maria Eugenia Suarez. ${ }^{a}$ Fruits were immature when collected (so they are not suitable for preparing aloja). ${ }^{\mathbf{b}}$ Because it has darker pods with brownish-reddish edges and thinner leaves

process varies: the higher the temperature and/or insolation, the shorter the process. Warm water may be added in order to accelerate the process.

The transformation of materials is a gradual process perceived through the senses. During the first $12 \mathrm{~h}$, the beverage is described as sweet (haqunek), which is a sign that it is not ready yet (kamaj, not yet). Then, aloja starts to "boil" (naway, boiling, or nawaylhi, effervescence), it naturally heats, and white (i-pelaj) froth (la$q u j)$ appears at the surface. After $24 \mathrm{~h}$, the solid matter emerges to the surface and lots of froth lie beneath it. At that moment, aloja is ready; it is "mature" (yu) (Fig. 3d), although the exact moment in which each person considers that it is at its optimal state may vary between 24 and $72 \mathrm{~h}$, as explained below.

Regarding its flavour (nij, taste/smell), all interviewees consider that aloja is aqoj (tasty) when it is ready, but specific descriptions vary. People describe it as entremezcla sal, azúcar y agrio (intermingles salt, sugar and sour) or entrevera un poco dulce y un poco amargo (it intermixes a bit of sweet and a bit of bitter). Wichí terms mostly used are tapay, which corresponds to bitter, sour
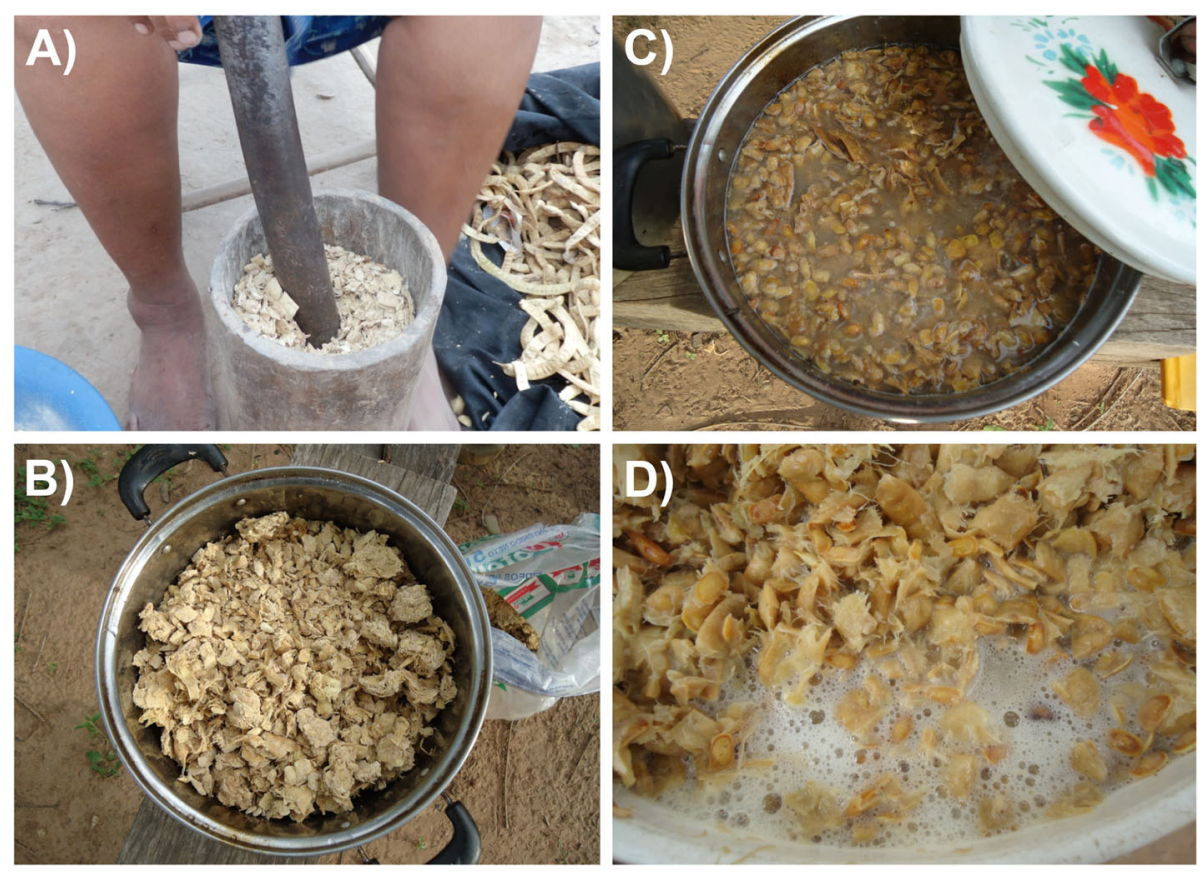

Fig. 3 Preparation of algarroba beer. a Grinding algarrobas in a wooden mortar. b Optimal size of the raw material, jwa'ay-Ihipey (algarrobas parts/pieces). c Algarroba beer at initial time. $\mathbf{d}$ Algarroba beer after $24 \mathrm{~h}$ of fermentation 
or spicy, and nusuy, which is applied to salty, sour or acid (see $[12,28]$ ). The first one applies mostly to the taste of aloja at $24 \mathrm{~h}$ and the second to aloja at 36-48 h. Interviewees remark that when the aloja se pasa (it passes), it can no longer be drunk because it is intoxicating, causing strong belly pains, vomits and/or diarrhoea. This occurs after $48 \mathrm{~h}$ of preparation, during the third day. At this point, taste is described as najut (ugly/rotten/foetid) or as nusuy if the previous phase was perceived as tapay. In sum, as the beverage matures, its flavour changes from haqunek (sweet) to tapay (bittersour), then to nusuy (salty-sour) and finally to najut (foetid). It is important to remark that in the past, during traditional festivities, the beverage was consumed in a relative short time and there were men in charge of looking after the whole process, so aloja never became rotten $[9,12]$.

\section{The strength of jwa'ay}

As said before, aloja is ready when it is $y u$. Palmer [13] points out that the term $y u$ means mature as well as cooked, which leads to the idea that fruit (of any species) maturation is a natural cooking process produced by the heat of the sun. In this sense, our results agree with his observations. Fermentation is at the same time a maturation and a cooking process in which heat (temperature and insolation) catalyses the intrinsic strength (qahay/qahayaj) of algarrobas, with alcohol generation: la ponen al rayo del sol y por eso sale alcohol. De la misma algarroba sale alcohol (when exposed to sunlight, alcohol appears; alcohol comes from the algarrobas itself). Interviewees say that if the strength increases, more alcohol is produced: a más fuerza, más machadora (the more strength, more intoxicating). Again, Palmer [13] affirms that an intrinsic property of the beverage, the nij (taste/smell), is responsible of the efficacy (intoxicating effect, alcohol content) of algarroba beer or any other alcoholic beverage. This is, once more, coincident with our data, as this property (nij) is the one that emerges and changes all along the fermentative process, evidencing the increase and transformation of the strength (qahay) of the beverage, which in turn produces $n i j$.

Considering the above, some details of the recipe become important and make absolute sense. Firstly, apart from being a hygiene measure (avoiding flies or dirt entering the liquid), covering the container is important for que no salga el vapor, la fuerza (the steam, the strength not coming out). Secondly, heat directly influences the fruits' qahay and thus the beverage's nij, explaining why the duration of the process depends on climatic conditions and the addition of warm water shortens it.

\section{Fresh, not stored}

Whatever kind of pods is used to prepare aloja, jwa'ay must be fresh (collected recently). As interviewees explain, fresh pods have the necessary "strength" (qahay, qahayaj) for the transformation to occur: La conserva no sirve para aloja. Sale bien amargo. No es rica (longstored algarrobas are not useful for aloja. It comes out bitter. It isn't tasteful). People say that aloja de algarroba is, essentially, a festive beverage, and as its consumption was limited to $P$. alba's fructification period, when the ancient algarroba festivities took place, fresh fruits were easily available. They explain that when aloja was needed for other rites (e.g. feminine initiation) in other seasons, alternative raw materials were used: honey, watermelon (Citrullus lanatus (Thunb.) Matsum. \& Nakai), mistol (Ziziphus mistol Griseb.), tusca (Acacia aroma Hook. \& Arn.) or palm (Copernicia alba Morong), among others. This fact is also mentioned by several authors (see [12, 13, 21, 29]).

The strict employment of fresh fruits is an aspect directly linked to the fermentative process from a biological perspective. Spontaneous alcoholic fermentations are due to the synergic metabolic activity of various microbial groups in different stages of the process $[4,5]$. In the case of algarroba beer, the predominant organisms are yeasts and lactic acid bacteria (LAB), the former being responsible for the alcoholic fermentation and the latter for the lactic fermentation. Both are mainly in the surface of the pods, constituting the epiphytic microbial flora of the fruit [22]. According to Sciammaro [22], when the beverage is prepared with fresh fruits, the fermentative process occurs as follows: during the first $24 \mathrm{~h}$ approximately, lactic fermentation prevails, which is evidenced by a marked $\mathrm{pH}$ decrease and a rise in the concentration of LAB. Then, yeast population increases considerably as the acid media favours its growth, and alcoholic fermentation takes place. At $48 \mathrm{~h}$, alcohol concentration is between $6.5 \%$ and $7.5 \%(\mathrm{v} / \mathrm{v})$ and LAB and yeast abundance of $10^{8}$ colony-forming units $(\mathrm{CFU} / \mathrm{ml})$ and $10^{7}(\mathrm{CFU} / \mathrm{ml})$, respectively. On the other hand, the experiment carried out by Herrera Cano [30] from fruits stored for 6 months at $4{ }^{\circ} \mathrm{C}$ showed somewhat different results: at $48 \mathrm{~h}, \mathrm{LAB}$ abundance was much higher $\left(10^{6}\right.$ times) than yeast abundance, and ethanol concentration was extremely low, around $0.02-0.03 \%$. It is known that when substrates are stored for large periods of time, a differential viability loss for the various inocula occurs, which results in an alteration of the original fermentative process. In this sense, it seems that for algarroba beer, an extended storage results in a prevalence of lactic fermentation over alcoholic fermentation, producing an acid/sour beverage, with a low-alcohol content. This reinforces the importance of using fresh fruits, as interviewees remark, and explains the perceived organoleptic 
characteristics of aloja when it is prepared with fruits stored for large periods.

\section{Grinding pods into what?}

Another important detail of the recipe is the final size of algarroba pods after grinding. As said before, for an appropriate transformation into aloja, fresh pods must be ground into pieces (lhipey) (Fig. 3b). Traditionally, Wichí people collect great amounts of algarrobas, dry them and store them up to several months. Either entire pods or flour can be stored. Flour is prepared by sieving ground dry pods to separate the powder from the seeds and pericarp pieces. Interviewees remark that aloja cannot be properly prepared with algarroba flour (jwa'a$m u k w$ ) alone, but that flour can be added to the lhipey to make it "stronger", "más machadora" (more intoxicating, with more alcohol).

Although some authors have noted that pod pieces are used (e.g. [31]), others mention this in a confusing manner (e.g. [12, 32]), others say that flour is the main ingredient (e.g. [13]), and others do not specify this aspect at all (e.g. $[9,28])$. However, at a microbiological level, interviewees' remarks can be explained. Yeasts and LAB are mainly in the surface of the pericarp. When using pod pieces (lhipey), tissues slowly disaggregate during the fermentation process, allowing dissolution of soluble components (mainly sugars) while microorganisms (inocula) disperse in the media (see $[22,30])$. Then, microbes get in contact with the sugary water and ecological succession starts. If only flour is used, there is a lesser amount of initial inocula and a faster sugar release, which may lead to an alteration of the appropriate fermentative process, not allowing to obtain tasty aloja.

\section{Aloja's containers}

Any container in which aloja is prepared is generically called hat'es-hi (aloja container). In the past, the container par excellence was a trough made of tsemlhokw (Ceiba chodatii (Hassl.) Ravenna), with a capacity of 20 $30 \mathrm{~L}$. The upper part was covered with the bark of the same trunk, a tsuhna (Mazama americana) skin or leafy new branches of Prosopis alba (jwa'ayuk-pesey) (Fig. 4), which don't interfere with the beverage's own taste, as interviewees explain. These data coincide with those of Arenas [12], who describes the material culture associated to aloja in detail.

According to some interviewees, for small reunions of individual consumption, smaller tsemlhokw troughs or barrels (3-10 L), ceramic vessels (10-15 L), large gourds (wotsotaj, Lagenaria siceraria (Molina) Standl.) (2-4 L) or skin container were used to prepare aloja. Regarding ceramic vessels, other authors have also registered their use (see [9, 12, 32, 33]), and our interviewees were all sure of this information. On the contrary, not all interviewees agree on the usefulness of skins as aloja container: some state that skins rot if aloja is prepared in it, while others affirm that skins from different animals could be used, depending on the needed size: rabbit (inote, Pediolagus salinicola) or vizcacha (ohnolo, Lagostomus maximus) for relative small containers and tsuhna (Mazama americana), tapir (yela, Tapirus terrestris) or cow for large ones. Although some authors mention the use of cow or tapir skins as aloja containers (e.g. [12, 29]), as Arenas [12] says, it is highly probable that their use started since the contact with the Criollos (mestizos) people and as replacements of old containers, when these were not available. In this line of thought, maybe small skins are relatively new too as aloja containers, and their use probably started when ceramic or gourd containers were not available as before.

At present, all the described containers are in disuse and have been replaced by plastic washbowls, bowls, jars or buckets or aluminium pots, which are covered with cloths or metal and plastic taps (Figs. 3, 4). All these items are of common use in the current daily lives of the Wichís. Finally, one may wonder whether algarroba beer prepared in industrial container tastes/smells different from that prepared in tsemlhokw, gourd, ceramic or skins. This is an interesting question for future studies, but a priori we suppose that it is highly probable, because while plastic and metal are relatively inert materials, old containers could have been providing their own microbial flora and other natural components, which would have affected the final organoleptic properties of jwa'ay-hat'es.

\section{Conclusions}

A detailed description of the preparation process of algarroba beer is provided, based on original information. Any kind of Prosopis alba fruit is useful, except jwa'ayt'ojes, as they have poor mesocarp. Aloja must be prepared with fresh (not long-stored) fruits, ground into pieces, not flour. The optimal fermentation time is 24 $48 \mathrm{~h}$; then it starts rotting. To obtain a higher alcoholic content, the fermentation process must be long, and/or algarroba flour may be added. Through the senses, mainly taste and smell, the process is followed until the optimal fermentation stage is reached: when aloja is ready it tastes tapay (bitter-sour) or nusuy (sour-salty). From a Wichí perspective, fermentation is a maturation and a cooking process, and it is an intrinsic property of the pods, their "strength", which allows fermentation to occur, with alcohol production. All interviewees' remarks on the recipe are also explained by microbiological concepts. Traditional containers were replaced by plastic and metal ones; as the former may have provided their own microbiota and chemical substances, the taste of algarroba beer is possibly quite different at the 


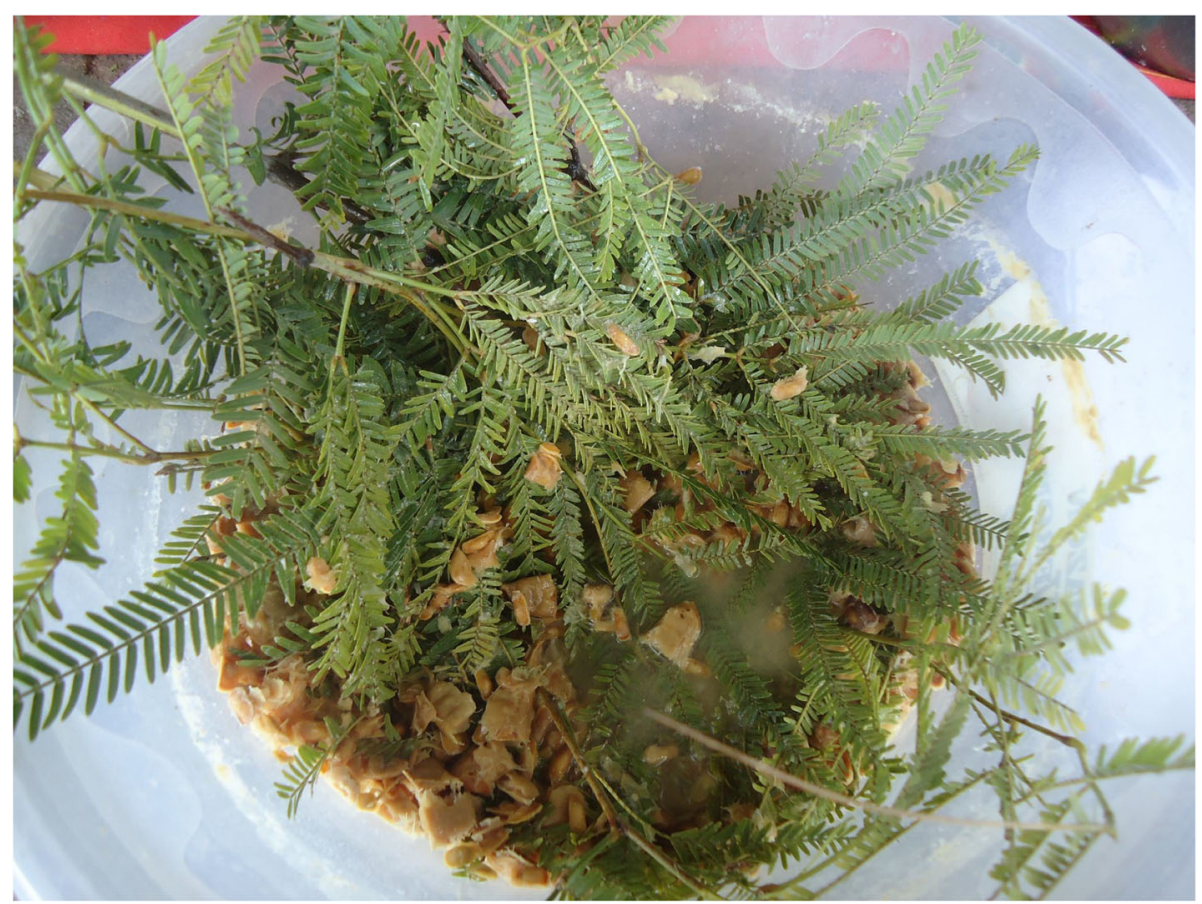

Fig. $4 \mathrm{Jwa}$ 'ayuk-pesey (leafy new branches of P. alba) covering the algarroba beer. In this example, recorded during fieldwork, a plastic bowl was covered with jwa'ayuk-pesey during the preparation of algarroba beer, although cloths or plastic taps are more at present. However, this technique was usually employed in the past when the beverage was prepared in large wooden troughs made of yuchán (Ceiba chodatii) during aloja festivities. During these ceremonies, the jwa'ayuk-pesey also served as colanders to retain seeds and other solids: solid matters were retained underneath the branches when cups or jugs were introduced into the container, i.e. branches were pushed to the bottom with the jug; hence, only liquid was taken

present. Altogether, results expand the knowledge on Wichí ethnobiology and are a detailed source of information useful to different disciplines interested in traditional food systems and to the rescue of the know-how on this traditional beverage for future generations and ultimately to food sovereignty.

\section{Acknowledgements}

To our Wichí friends and colleagues, in the hope of contributing to demonstrate your profound relation with the environment and your rightful territorial sovereignty.

\section{Authors' contributions}

Both authors contributed equally to the manuscript.

\section{Funding}

This research was partially financed by CONICET, ANPCYT (PICT 2013-1633 and 2013-2190) and UBA (UBACYT 20020170200233BA and 20020150200191BA).

\section{Availability of data and materials}

Background materials (plant vouchers) are deposited in the herbaria of Museo Argentino de Ciencias Naturales "Bernardino Rivadavia", Buenos Aires, Argentina (BA). Original information collected through interviews and recorded in field books are kept at the workplace of the authors.

\section{Competing interests}

The authors declare that they have no competing interests.

\section{Author details}

'Departamento de Biodiversidad y Biología Experimental, Grupo de Etnobiología, Facultad de Ciencias Exactas y Naturales, Universidad de
Buenos Aires, Buenos Aires, Argentina. ${ }^{2}$ Centro de Estudios Farmacológicos y Botánicos (CEFYBO), CONICET-UBA, Buenos Aires, Argentina. ${ }^{3}$ Instituto de Micología y Botánica (INMIBO), CONICET-UBA, Buenos Aires, Argentina.

Received: 28 July 2019 Accepted: 19 November 2019

Published online: 14 January 2020

\section{References}

1. Nabhan GP. Ethnobiology for a diverse world: microbial ethnobiology and the loss of distinctive food cultures. J Ethnobiol. 2010. https://doi.org/10, 2993/0278-0771-30.2.181.

2. Pieroni A, Pwaera L, Ghulam MS. Gastronomic ethnobiology. In: Albuquerque UP, Nóbrega Alves RR, editors. Introduction to Ethnobiology. Switzerland: Springer International Publishing; 2016. p. 53-62.

3. Caplice E, Fitzgerald GF. Food fermentation: role of microorganism in food production and preservation. Int J Food Microbiol. 1999;50:131-49.

4. Scott R, Sullivan W. Ecology of fermented foods. Hum Ecol Rev. 2008;15(1): 25-31.

5. Mc Kay M, Buglass AJ, Lee CG. Fermented beverages: beers, ciders, wines and related drinks. In: Buglass AJ, editor. Handbook of Alcoholic Beverages, Analytical and Nutritional Aspects Vol. 1. Malasya: Wiley; 2011. p. 63-454.

6. Madej T, Pirożnikow E, Dumanowski J, Łuczaj L. Juniper beer in Poland: the story of the revival of a traditional beverage. J Ethnobiol. 2014. https://doi. org/10.2993/0278-0771-34.1.84.

7. Lozano PSJ. Descripción Corográfica del Gran Chaco Gualamba. Tucumán: Universidad Nacional de Tucumán; 1989[1733].

8. Métraux A. Ethnography of the Chaco. In: Steward JH, editor. Handbook of South American Indians Vol. 1. Washington: Bulletin of 143 Smithsonian Institution; 1946. p. 197-370.

9. Pelleschi G. Eight months on the Gran Chaco of the Argentine Republic. London: Sampson Low, Marston, Searle \& Rivington; 1886.

10. Burkart A. A monograph of the genus Prosopis (Leguminosae subfam Mimosoideae). J Arnold Arboretum. 1976;57(4):450-525. 
11. Gardenal G. Algarroba, algarroberas y algarrobales. Fruto, mujer y territorio en torno al árbol en la región del Gran Chaco, Argentina. In: Eyzaguirre M, Villanueva J, Taboada F, Oros V, Fernández MS, Salazar L, Carvajal I, Condarco C, editors. Rebelión de los objetos: cestería y maderas. Anales de la Reunión Anual de Etnología. Bolivia: Museo Nacional de Etnografía y Folklore; 2017. p. 11-31.

12. Arenas P. Etnografía y Alimentación entre los Toba-Nachilamole\#ek y WichiLhuku'tas del Chaco Central (Argentina). Buenos Aires: Pastor Arenas Ed.; 2003.

13. Palmer J. La Buena Voluntad Wichí: una espiritualidad indígena. Las Lomitas: Grupo de Trabajo Ruta 81; 2005.

14. INDEC. (Instituto Nacional de Estadística y Censos). Censo Nacional de Población, Hogares y Viviendas 2010. Censo del Bicentenario. Resultados definitivos. Serie B №2. Tomo 1. Buenos Aires: Instituto Nacional de Estadística y Censos; 2012.

15. INE (Instituto Nacional de Estadística. Estado Plurinacional de Bolivia). Censo de Población y Vivienda 2012. http://censosbolivia.ine.gob.bo. Accessed 20 Jul 2019.

16. Golluscio LA, Vidal A. Recorrido sobre las lenguas del Chaco y los aportes a la investigación lingüística. In: Golluscio LA, Vidal A, editors. Les Langues du Chaco. Structure de la phrase simple et de la phrase complexe. Amerindia 33/34; 2010. p. 3-40

17. Suárez ME. Etnobotánica Wichí del bosque xerófito en el Chaco Semiárido Salteño. Buenos Aires: Autores de Argentina; 2014.

18. Dasso MC. Celebración de la aloja: la preservación del fundamento mítico entre los Mataco-Wichí del Chaco Central. Sripta Ethnologica. 2001;22:61-76.

19. Barúa G. Lo "eterno" y lo "fugaz": el ritual del Yachep entre los Wichí bazaneros. Archivos del Departamento de Antropología Cultural del CIAFIC. 2004;2(1):188-214

20. Lunt R. Cien años de la misión Anglicana en el Norte Argentino. Formosa: Diócesis de la Iglesia Anglicana en el Norte Argentino; 2011.

21. Alvarsson JA. Etnografía 'weenhayek, volumen 1. Campear y Pescar. La organización socio-económica y política. Uppsala: Dissertations and Documents in Cultural Anthropolgy N¹1; 2012.

22. Sciammaro LP. Caracterización fisicoquímica de vainas y harinas de algarrobo (Prosopis alba y Prosopis nigra). Aplicaciones en productos horneados y fermentados. La Plata: Universidad Nacional de La Plata. Facultad de Ciencias Exactas; 2015.

23. Arenas $\mathrm{P}$, Martínez $\mathrm{G}$. Estudio etnobotánico en regiones áridas y semiáridas en Argentina y zonas limítrofes. Experiencias y reflexiones metodológicas de un grupo de investigación. In: Arenas P, editor. Etnobotánica en Zonas Áridas y Semiáridas del cono sur de Sudamérica. Buenos Aires: CEFYBOCONICET; 2012. p. 11-43.

24. Wahyuni $\mathrm{D}$. The research design maze: understanding paradigms, cases, methods and methodologies. JAMAR. 2012;10:69-80

25. Albuquerque UP, Fernandes Cruz da Cunha LV, Paiva de Lucena RF, Nóbrega Alves RR. Methods and techniques in ethnobiology and ethnoecology. New York: Humana Press; 2014.

26. Palacios RA, Bravo LD. Hibridación natural en Prosopis (Leguminosae) en la región chaqueña argentina. Evidencias morfológicas y cromatográficas. Darwiniana. 1981;23(1):3-35.

27. World Flora Online. http://www.worldfloraonline.org. Accessed $22 \mathrm{Jul} 2019$.

28. Maranta A. Los recursos vegetales alimenticios de la etnia Mataco del Chaco centro occidental. Parodiana. 1987;5:161-237.

29. Karsten R. La religión de los indios Mataco-noctenes de Bolivia. Anales del Museo Nacional de Historia de Buenos Aires. 1913;24:199-218.

30. Herrera Cano AN. La aloja de algarroba (Prosopis alba) de los Wichís del Gran Chaco: aspectos etnobiológicos y microbiológicos de su elaboración y consumo. Buenos Aires: Universidad de Buenos Aires. Facultad de Ciencias Exactas y Naturales; 2015.

31. Torres GF, Santoni ME, Romero LN. Los Wichí del Chaco Salteño Ayer y Hoy. Alimentación y Nutrición. Salta: Crisol; 2007.

32. Baldrich JA. Las comarcas vírgenes. El chaco central norte. Buenos Aires: Casa Editora Imprenta, Litografía y Encuadernación de Jacobo Peuser; 1889.

33. Alvarsson JA. Etnografía 'weenhayek, volumen 3. Belleza y Utilidad. La cultura material. Uppsala: Dissertations and Documents in Cultural Anthropolgy N¹1; 2012

\section{Publisher's Note}

Springer Nature remains neutral with regard to jurisdictional claims in published maps and institutional affiliations.

Ready to submit your research? Choose BMC and benefit from:

- fast, convenient online submission

- thorough peer review by experienced researchers in your field

- rapid publication on acceptance

- support for research data, including large and complex data types

- gold Open Access which fosters wider collaboration and increased citations

- maximum visibility for your research: over $100 \mathrm{M}$ website views per year

At $\mathrm{BMC}$, research is always in progress.

Learn more biomedcentral.com/submissions 